\title{
The International Legal Center, New York
}

The International Legal Center was established in New York in 1966, with the support of the Ford Foundation, to co-operate with the developing nations. A report on the status and future of law and development is being prepared by a committee with members drawn from Latin America, Asia, Africa, Europe, and the United States. A Committee on Legal Education in the Developing Countries has also been established and is preparing for publication a report on contemporary legal education in these countries, to assess its contribution to the formation of persons trained in law to meet developmental needs and to suggest guidelines for further strengthening of legal education and for international collaboration in this field. An Overseas Service Fellowship Program has been designed to provide recent law graduates with field experience and to assist the host institutions of the developing countries in theit innovative programmes. The African side of the Fellowship Program has sought to strengthen African law faculties and to facilitate their Africanization and a strong tie has been developed between African and American legal scholars and law faculties. Since 1966,76 African scholars from I 4 countries have received support or participated in programmes supported by the ILC.

\section{African-American Labor Center: Documentation Center at Lomé}

The African-American Labor Center was founded in 1965, with headquarters in New York, and is interested in the fields of vocational training, development of co-operatives, training of trade-union leaders, health, and housing. It has 18 full-time employees working in 32 African countries, giving advice on organization of labour, training, and related problems. It has recently established a Regional Economic Research and Documentation Center at Lomé, Togo (B.P. 71 138) under the direction of George R. Martens, which aims to provide African trade unions and other organizations with economic research material and analysis on request. It will also publish new data and reprints of relevant published material for general use and hopes to organize seminars and conferences so that the individual unions may develop adequate research units with trained staff capable of providing their own research material. At present most of its published material is in French, since it is currently serving only Francophone African unions, but it is hoped to establish ties with similar organizations in Africa and in Europe.

\section{University of Dar es Salaam: Economic Research Bureau}

THe Economic Research Bureau of the University of Dar es Salaam is the main agency of economic research in Tanzania and co-operates with the Tanzania Government in assessing the country's needs in its socialist development effort. The collected papers of the Bureau, 1966-71, which include some restricted papers not previously available to the general public, are shortly to be published in five volumes. Full details on request from the Economic Research Bureau, University of Dar es Salaam, P.O. Box 35096, Dar es Salaam, Tanzania.

\section{African Manuscripts in the Birmingham University Library}

THE Library has several collections devoted entirely to Africa, also collections which contain some Africana. The following is a list of the most important materials:

\section{Bradbury Papers}

The papers of the late Dr. R. E. Bradbury, who was on the staff of the University's Centre of West African Studies. These consist of field notes made during three field tours in Benin, 195I-6r. 